\title{
Aspects of Legitimacy of Decisions of International Courts and Tribunals*
}

\author{
Aspectos da Legitimidade das Decisões de Cortes e Tribunais Internacionais
}

Tullio Treves

Università degli Studi di Milano, Milão - Italía

\begin{abstract}
The article analyzes some aspects of legitimacy of decisions of international courts and tribunals. It starts the analysis from a series of questions touching upon the potential aspects of legitimacy. The author firstly put international judicial decisions to the test of Thomas Franck's indicators of legitimacy. Then, he focuses on some examples of practices aimed at "legitimizing" or "de-legitimizing" international decisions within the Goldstone meaning of legitimacy.
\end{abstract}

Keywords: Legitimacy. International Judicial Decisions. International Courts and Tribunals.
Resumo: $\mathrm{O}$ artigo analisa alguns aspectos da legitimidade das decisões de cortes e tribunais internacionais. O ponto de partida da análise é uma série de questões tocando potenciais aspectos da legitimidade. $\mathrm{O}$ autor primeiramente aplica o teste dos indicadores de legitimidade de Thomas Franck às decisões judiciais internacionais. Em seguida, o autor foca em alguns exemplos de práticas voltadas a "legitimar" ou "deslegitimizar" decisões judiciais por meio do conceito de legitimidade desenvolvido por Goldstone.

Palavras-chave: Legitimidade. Decisões Judiciais Internacionais. Cortes e Tribunais Internacionais.

\section{Introduction: Legality and Legitimacy: objective and subjective legitimacy}

In considering the use of force outside the parameters of the U.N. Charter, the expression "illegal, but legitimate" has been used, in

\footnotetext{
* This article was originally published in R. Wolfrum and V. Roben (eds) Legitimacy in International Law, 2008.
}

Recebido em: 04/08/2016

Revisado em: 10/01/2017

Aprovado em: 30/01/2017 
particular in the Goldstone report ${ }^{2}$. In that context, legitimacy as opposed to legality is used to indicate a judgement based on values different from those of conformity with the law. These values include moral principles such as the safeguarding of human life and dignity. "Legitimate" indicates a perception of acceptability in light of these values.

There are also other ways of looking at legitimacy. It seems particularly interesting to consider the notion put forward by Thomas M. Franck. He proposes that legitimacy be verified in light of correspondence with certain "indicators". These indicators, as put forward by Franck, are not directly of a moral nature. They belong to legal discourse, although lack of correspondence with them does not have as a consequence that legality in a specific case is put into question. Franck's indicators are: determinacy, symbolic validation, coherence and adherence ${ }^{3}$.

A judgement of legitimacy, especially if used according to the "Goldstone" meaning, when coupled with a judgement of illegality, expresses a criticism of the law, or a claim to change the law, or a claim to some form of justification. While "legality", i.e. conformity to the law, is a fundamental parameter of legitimacy both in the "Goldstone" and the "Franck" sense, a judgement of "legitimacy" or "illegitimacy" may also be used in addition to a judgement of "legality" (legal and legitimate, legal but illegitimate). In this case, when the requirements of legitimacy (used either way) are satisfied, something is added to "legality"; when they are not satisfied ("illegitimacy") something is subtracted from it; this "something" being a perception of acceptability. In determining whether the requirements set out in the "indicators" of legitimacy proposed by Tom Franck are satisfied, different persons may of course reach different conclusions. This determination can nevertheless be considered an "objective" one as it is based on judgements that can be made on the basis

2 Independent International Commission on Kosovo, The Kosovo Report: Conflict, International Response, Lessons Learned, 2000, at 164.

${ }^{3}$ T. Franck, Fairness in International Law and Institutions, 1995, at 30-46. In the following, I will refer to this book. Franck has, however, addressed legitimacy in a number of other works, especially The Power of Legitimacy among Nations, 1990; and, most recently, "The Power of Legitimacy and the Legitimacy of Power: International Law in the Age of Power Disequilibrium", AJIL 100 (2006), 88-106. 
of legal technique ${ }^{4}$. Even though the acceptance of these indicators as relevant may be seen to be based on a value judgement, in determining their applicability to a specific case no such judgement is necessary.

When used in the "Goldstone" sense, the judgement of "legitimate" or "illegitimate" is directly based on value judgements. In this sense, it can always be considered subjective. It seems, however, preferable to use this adjective only when the judgement is based on values held important by one State or by a group of States, and to indicate as "objective" such judgement when based on values broadly or generally shared. In most cases the values invoked to claim legitimacy or illegitimacy within the Goldstone meaning are broadly accepted, while what is not always broadly accepted is the judgement that these values must, in the specific case, prevail over other values not less broadly accepted. The borderline between subjective and objective judgement of legitimacy is thus not entirely clear, as subjective legitimacy is more often than not a claim that certain generally shared values should prevail over others in a specific case.

I. Legitimacy of judicial decisions the legality of which is not questioned.

When discussing legitimacy as regards judicial decisions, it seems particularly interesting to deal with the legitimacy of decisions the legality of which is not questioned. While not ruling out that there may be decisions the legality of which is questioned or questionable and the legitimacy of which may be discussed for that reason, the focus of the brief remarks that follow will be on factors that can add to or subtract from the legitimacy of a decision validly adopted.

In assessing the legitimacy of international judicial decisions, it may be interesting to consider a series of questions. The reader will recognize that these questions, although grouped in six clusters, follow

4 P.-M. Dupuy, "L'unité de l'ordrejuridique international, Coursgénéral de droit international public", Recueil des cours, vol. 297, 2002, 9 at 405, ftn. 813 observes that Franck's notion of legitimacy is closer to the notion of legality as traditionally understood in European political and legal philosophy than to the notion of legitimacy upheld by that philosophy. 
the classification of legitimacy theories in three groups, as clearly put forward, for example, by Daniel Bodansky5: source-based theories (the first two clusters), process-based theories (the third and fourth clusters), and outcome-based theories (the fifth and sixth clusters).

The first cluster concerns the way the judicial body is established. The following questions may be considered:

- is a judicial body more legitimate when it is treaty-based, or when it is based on a Chapter VII resolution of the Security Council?

- is a judicial body that considers State-to-State disputes less legitimate if it has been established without the participation of some of the States which may become parties to cases before it (or the State that necessarily will be such a party)?

The second cluster has to do with the members of the judicial body. The following questions may be of interest:

- is a judicial body more legitimate when its members are elected or when they are designated?

- does the legal expertise of the members or the right political mix in the composition of the judicial body contribute more to the body's legitimacy?

- how important are the guarantees of impartiality and independence of the judicial body's members, and the record of their implementation, for the legitimacy of the decisions?

- how relevant is the quality of the previous judgements for the legitimacy of a specific decision?

The third cluster concerns the basis of jurisdiction. In particular, the following questions seem of interest:

- is a decision taken by a judicial body on the basis of a special agreement on jurisdiction more legitimate than one in which jurisdiction

5 See D.Bodanski, The Concept of Legitimacy in International Law, in R. Wolfrum and V. Roben (eds) Legitimacy in International Law, 2008, p. 309 at 310 et seq. 
is based on a rule providing for compulsory jurisdiction or on the ICJ's optional clause?

- is a decision taken on the merits after a divisive battle has been fought on preliminary questions less legitimate than a decision taken when no such battle has been fought or when the preliminary questions have been solved by a broad majority of the judicial body?

The fourth cluster includes questions having to do with how judgements are reached. Among those to be considered are the following:

- are judgements made in proceedings in which one party has not appeared less legitimate than those in which all parties participate?

- are judgements made in proceedings in which there is a lack of balance in the means (human and material) at the disposal of the defence of the parties less legitimate than those where such balance exists?

The fifth cluster concerns the characteristics of the decision. Relevant questions seem to be the following:

- is the legitimacy of the decision influenced by the fact that it has been taken by an unanimous vote, or by a majority, or with the casting vote of the president?

- is the legitimacy of the decisions influenced by the presence of numerous declarations, separate or dissenting opinions?

- is the legitimacy of the decision influenced by lack of clarity of the operative part and/or of the reasons?

- is the legitimacy of a decision influenced by the fact that certain questions raised in the pleadings are not addressed or are addressed very shortly?

- is the legitimacy of a decision influenced by the fact that it addresses questions that have not been discussed, or which are irrelevant for the decision as it has been taken?

- is the legitimacy of the decision influenced by its consistency with previous judgements of the deciding body? 
- is the legitimacy of the decision influenced by its taking into account of the existence, jurisdiction and jurisprudence of other internationaljudicial bodies?

The sixth and last cluster has to do with the effects of the decision. Thefollowing question seems relevant:

- does the legitimacy of a decision have an influence on its implementation?

To address all these questions (and others that could be raised) in some detail would require extensive research and much more space than is available for the present paper. Raising these questions must be seen as an exploration of the territory to be covered in future studies. To draw a sketch of the possible answers would not be an impossible task, but the results might be misleading as based more on impressions than on fully fledged research. It seems preferable to consider two separate, specific, areas in the discussion of which the treatment of a few of the questions set out above may emerge.

I will try, first, to put international judicial decisions to the test of Thomas Franck's indicators of legitimacy. I will later focus on some examples of practices aimed at "legitimizing" or "de-legitimizing" international decisions within the Goldstone meaning of legitimacy.

\section{Franck's tests of Legitimacy and International Judicial Decisions}

The decisions of judges are included, according to Franck, within the scope of the four indicators of legitimacy mentioned above, as these indicators concern "the legitimacy of primary rules, the ordinary rules, whether made by legislatures, bureaucrats, judges or plebiscites." ${ }^{6}$ This notwithstanding, decisions of judges are not examined closely in Franck's analysis of the four indicators. This makes it particularly interesting to try this examination. What follows is an attempt to develop ideas taking Franck's indicators as a point of departure. Of course, I do not claim that

\footnotetext{
${ }^{6}$ Franck, Fairness, note 2, at 26.
} 
these developments are entirely consistent with Tom Franck's thought or that he would agree with them.

Determinacy is the first of the four indicators. It consists in "the ability of a text to convey a clear message ... Rules which have a readily accessible meaning and say what they expect of those who are addressed are more likely to have a real impact on conduct." ${ }^{\prime 7}$ Decisions of international courts and tribunals may fail this test if their operative part is unclear, avoids answering the questions addressed to the adjudicating body or if the reasons given are difficult to understand or may be subject to different interpretations. One can also wonder whether different reasons given for a certain position adopted, indicating that some apply only where other reasons are rejected, is consistent with this test.

The well known para. 2E of the operative part of the ICJ's advisory opinion of 8 July 1999 on the legality of the threat or use of nuclear weapons (adopted by seven votes to seven, with the casting vote of the President $)^{8}$ may be an example. In answering the rather clear question "is the threat or use of nuclear weapons in any circumstance permitted under international law?" the Court, in the key para. just indicated, states that: "the threat or use of nuclear weapons would generally be contrary to the rules of international law applicable in armed conflict, and in particular the principles and rules of humanitarian law". It adds that: "[...] the Court cannot conclude definitively whether the threat or use of nuclear weapons would be lawful or unlawful in an extreme circumstance of self-defense, in which the very survival of a State will be at stake". Even taking into account the difficulty of the question and its political impact, and the fact that the decision is an advisory opinion and not a judgement, it seems evident that the phrase "would generally be contrary" and the assertion that the Court "cannot conclude definitively" do not convey a clear meaning. The dissent of Judge Rosalyn Higgins argues exactly this point: "The findings in a judicial dispositif should be clear. I believe that para. $2 \mathrm{E}$ is unclear in its meaning". Such lack of clarity, in Judge Higgins' view,

\footnotetext{
${ }^{7}$ Franck, Fairness, note 2, at 30-31.

${ }^{8}$ ICJ Reports 1996, 226. Adoption with the casting vote of the President may by itself raise questions of legitimacy, as mentioned in the previous paragraph.
} 
brings the Court to a non liquet. Judge Higgins also deplores the fact that the Court does not "show the steps by which it reaches its conclusions." This view is shared in the declaration of one of the judges in the majority, Judge Ferrari Bravo, who states that the reasoning of the Court "is often difficult to read, tortuous and ultimately rather inadequate." 10

It may be argued that such lack of clarity takes something away from the Advisory Opinion's legitimacy. It could well be, however, that the other options open to the Court would have taken away something more. These options were, in particular, using its discretion in refusing to comply with the request of the General Assembly, and giving a clear, yes or no, answer to the question including the possible nuances that the expression "in any circumstance" contained in it could have permitted.

The second indicator of legitimacy proposed by Franck, symbolic validation, seems an inherent characteristic of international judicial decisions. The formality of the proceedings and of the reading of the judgement, the detailed character of the reasoning, the connections with the United Nations that exist in many international courts and tribunals, all signal that an international judgement, to use Tom Franck's words, "is a significant part of the overall system of social order" 11 . From this viewpoint, it is unlikely that indications of illegitimacy can be found in the judgement of an international court or tribunal.

Coherence, the third indicator of legitimacy mentioned by Franck, if applied to international judicial decisions, would seem to require that decisions are in some measure predictable in light of previous decisions because like cases are treated alike and because "when distinctions are made, they must themselves be explicable by reference to generally applied concepts of differentiation." 12 Decisions taken - as happens quite often - on the narrowest possible ground, preferring what Georges Abi-

\footnotetext{
${ }^{9}$ ICJ Reports 1996, 583, para.s 7 and 9 at p. 584.

${ }^{10}$ ICJ Reports 1996, 282, at p. 283.

${ }^{11}$ Franck, Fairness, note 2, at 34.

${ }^{12}$ Franck, Fairness, note 2, at 39.
} 
Saab calls "solutions transactionnelles" to solutions based on principle, ${ }^{13}$ may be expedient and politically acceptable, and so ultimately fair and legitimate, as Franck seems to imply. ${ }^{14}$ They may nevertheless also be seen as subtracting something from the "legitimacy" of the decision as they avoid an assessment in light of the "coherence" indicator. The remark by Abi-Saab that this kind of decision may imply "une diminution significative du rôle de la Courcomme la plus haute instance judiciairedansl'ordrejuridique international"15, or that of Pierre-Marie Dupuy that it may jeopardize the Court's "rôle naturel de garant de l'unitéd'interprétation du droit international"16, seem to point in the same direction.

In light of the multiplication of international courts and tribunals, and of the consequent multiplication of international decisions in which international legal rules are ascertained and interpreted, a further aspect of "coherence" as an indicator of legitimacy may be envisaged. An attitude of different courts and tribunals based on knowledge of each other's decisions, mutual respect, avoidance of unnecessary conflicts seems to contribute to the "coherence" of judicial decisions and thus to their legitimacy. Recourse by courts involved in cases in which other courts are or may also be involved to notions such as "comity" and "judicial economy" may be useful ${ }^{17}$. So may be the development of trans-judiciary general procedural principles or customary rules ${ }^{18}$.

${ }^{13}$ G. Abi-Saab, "Coursgénéral de droit international public", Recueil des Cours 207 (1987-VII), 9, at 271

${ }^{14}$ Franck, Fairness, note 2, at 331.

${ }^{15}$ Abi-Saab, note 12, at 272.

${ }^{16}$ P.-M. Dupuy, note 3, at 476.

${ }^{17}$ T. Treves, "Judicial Lawmaking in an Era of "Proliferation" of International Courts and Tribunals: Development or Fragmentation of International law?", in: R. Wolfrum/V. Röben (eds), Developments of International Law in Treaty Making, 2005, 587-620; id., "Le Tribunal international du droit de la merdans la pléiade des juridictionsinternationales", in: O. Delas, R. Côté, F. Crépeau\& P. Leuprecht (eds.), Les juridictionsinternationales: complémentaritéou concurrence?, 2005, 9-39.

${ }^{18}$ See the stimulating essay by R. Kolb, "General Principles of Procedural Law”, in: A. Zimmermann, Ch. Tomuschat\& K. Oellers-Frahm (eds.), The Statute of the International Court of Justice, A Commentary, 2006, 793-835. 
A similar aspect of "coherence" may be envisaged in considering the relationship between the jurisdiction of the international judicial body that has adopted or may adopt a decision, and especially of the International Court of Justice, with the competence of an organ of the United Nations, such as the General Assembly and the Security Council. Concerns of legitimacy are probably to be seen in the attitude of the ICJ in the Lockerbie cases ${ }^{19}$. In recalling the Lockerbie provisional measures orders, in general terms Franck addresses this question, stating that: "the ICJ must give due weight to decisions of another organ interpreting its Charter-based jurisdiction" 20 . A concern for legitimacy (and not only for avoidance of conflict) may also be seen in the provision of article 298, para $1 \mathrm{c}$, of the United Nations Convention on the Law of the Sea which permits a State party, by a declaration, to exclude from compulsory jurisdiction provided for disputes concerning the interpretation or application of the Convention, "disputes in respect of which the Security Council of the United Nations is exercising the functions assigned to it by the Charter of the United Nations [...]".

Adherence, the fourth indicator of legitimacy proposed by Franck, is based on the fact that rules "are demonstrably supported by the procedural and institutional framework within which the community organizes itself." ${ }^{21}$ It would seem that this indicator of legitimacy is the closest to a test of legality. As regards decisions of international courts and tribunals, it would seem to include the fact that the court and tribunal has been established in application of legal rules and that it is competent according to the applicable rules. Concerns whether a court or tribunal was established in correct application of the existing rules, such as those discussed in the Tadic case by the International Tribunal

\footnotetext{
${ }^{19}$ Case concerning questions of interpretation and application of the 1971 Montreal Convention arising from the aerial incident at Lockerbie, Libya v. United Kingdom, Libya v. United States, provisional measures, Orders of 14 April 1992; ICJ Reports 1992, 114 and Judgements on preliminary objections of 27 February 1998, ICJ Reports 1998, 9. (see in particular the dissent by Judge Jennings, p. 99, espe. p. 108).

${ }^{20}$ Franck, note 2, at 331.

${ }^{21}$ Franck, note 2, at 41.
} 
for crimes committed in former Yugoslavia, ${ }^{22}$ may certainly be considered, as they were in the Tadic case, from the point of view of legality. They may, however, also be seen as raising a question of legitimacy, which is an aspect of the question that can be envisaged in more general terms, regarding the use, and sometimes alleged abuse, of "legislative powers" by the Security Council.

\section{Legitimacy of Judicial Decisions in Light of their Consistency with Moral or Political Values}

Coming now to legitimacy in the "Goldstone" sense, there can be many occasions on which a judicial decision may be argued to be "illegitimate" because it collides with values of a moral nature. Situations in which the jurisdiction of the judge, and consequently the scope of the judgement, can encompass only a limited part of a broad conflict may bring courts and tribunals to issue a judgement that some may see as illegitimate because it fails to address aspects of the conflict they consider essential in light of moral or political values. These values may often be incorporated in rules the application of which is beyond the limits of the jurisdiction of the court or tribunal. In these cases the concern for "legitimacy" as conformity with moral or political values collides with what we can call "the legitimacy of legality". In other words: the claim that the judicial decision should address certain issues and values even when they are beyond the limits of the court's jurisdiction, or are unnecessary to solve the dispute, collides with the argument that a value, the moral or political weight of which is considered essential, is that courts and tribunals do not, in their decisions, go beyond what has been brought before them according to the applicable rules.

In recent cases the ICJ has made statements in the situations just described linking the matter submitted to it to rules incorporating values it considers essential even when it decided that it lacked jurisdiction (or

22 Appellate Chamber, Decision on the Defence motion for interlocutory appeal on Jurisdiction, the Prosecutor v. D. Tadic, 2 October 1995, 35 ILM 32 (1996). 
prima facie jurisdiction in provisional measures proceedings) or when the statements were of no legal relevance for the decision taken in the case.

In another study, I have labelled this kind of statement "political obiter dicta. ${ }^{.23}$ In the context of the present paper, such statements can be called "legitimizing statements" as they can be seen as tools used by the Court to strengthen the legitimacy of the judgements or orders in which they are contained. A judgement or order that decides a case which emerges from a broad conflict that jeopardizes essential values such as those connected with loss of human life, genocide, use of force, on the basis of rather technical legal arguments such as those concerning lack of jurisdiction, may be more acceptable to the losing party and to public opinion if it contains statements - however unnecessary - that reaffirm these values. The same need of broad acceptability may well be an essential component of the decision-making process of the Court, as it may be easier for certain judges to concur with a decision taken on a basis not involving the application of rules incorporating moral values deemed essential if some mention of such rules is set out in the decision. It would seem that these judges, and also the losing State and public opinion are, through these statements, encouraged to see the decision as more legitimate.

The inclusion of "legitimizing statements" in recent decisions of the ICJ has to be seen in contrast with separate or dissenting opinions arguing in favour of the "legitimacy of legality", arguing, in other words, that these statements - independently of their legality, which in some cases is seen as doubtful - are unnecessary to support the decision and, especially, inopportune from the point of view of the proper exercise of the judicial function. These separate and dissenting opinions see the "legitimizing statements" included in the decisions with the purpose of connecting them with important legal and moral principles, as delegitimizing elements that subtract from the overall acceptability of judicial decisions. The subjective character of the idea of legitimacy of judicial decisions

\footnotetext{
${ }^{23}$ The Political Use of Unilateral Applications and Provisional Measures Proceedings, in: Verhandelnfuer den Frieden, Negotiating for Peace, Liber AmicorumTonoEitel, Frowein, Schariot, Winkelmann \&Wolfrum, eds., 2003, 463-481.
} 
emerges clearly in this opposition of views, not because the values invoked are not broadly shared, but because of the difference as to which one should prevail.

Two examples from recent cases considered by the ICJ seem to illustrate the points just made. They are the 2002 Order in the Armed Activities (Congo v. Rwanda) ${ }^{24}$ case and the 2003 judgement in the Oil platforms case (Iran v. United States) ${ }^{25}$.

In the Congo v. Rwanda order the Court refused the requested provisional measures, stating that it did not have prima facie jurisdiction (lack of jurisdiction was later confirmed in the 2006 judgement on jurisdiction and admissibility ${ }^{26}$ ). Notwithstanding the fact that the dispositif stated lack of prima facie jurisdiction, the Court emphasized that parties "must act in conformity with their obligations pursuant to the United Nations Charter and other rules of international law"27 and stressed "the necessity for the parties to these proceedings to use their influence to prevent the repeated grave violations of human rights and international humanitarian law." ${ }^{28}$ In support of this approach Judge Koroma, in his declaration, indicated that "the Court, in accordance with itsobiter dicta in the cited paras, nevertheless discharged its responsibilities in maintaining international peace and security" and stated that: "The position taken by the Court can only be viewed as constructive ... It is a judicial position and it is in the interest of all concerned to hearken to the call of the Court" ${ }^{\prime 29}$.

The opposite view emerges in Judge Buergenthal's declaration ${ }^{30}$. Leaving aside his argument that these statements were inappropriate "as

\footnotetext{
${ }^{24}$ Order of 10 July 2002, 41 ILM 1175 (2002).

${ }^{25}$ Judgement of 6 November 2003, Iran v. United States, 42 ILM 1334 (2003).

${ }^{26}$ Case concerning armed activities on the territory of the Congo (new application 2002), judgement of 3 February 2006, 45 ILM 562 (2006).

27 Para. 56.

${ }^{28}$ Para. 93. See also para.s 54 and 55.

${ }^{29} 41$ ILM 1197 (2002) para. 16.

3041 ILM 1199 (2002).
} 
a matter of law," ${ }^{31}$ for our present purposes it is interesting to note that he placed himself on the terrain of legitimacy in considering them something detracting from the authority of the Court or inappropriate. He states that these statements "[...] despite their admittedly "feel-good" qualities, have no legitimate place in this Order" 32 . In connection with the statement concerning the Court's responsibilities in the maintenance of peace and security, Judge Buergenthal states: "Of course, how could it be otherwise? Is it an apologia for the Court's lack of jurisdiction to do what it would like to do in this case? If so, I wonder whether it is appropriate." ${ }^{33} \mathrm{He}$ also stated: "Whether intended or not, the Court's pronouncements [...] might be deemed to lend credence to the factual allegations submitted by the Party seeking the provisional measures. In the future they might also encourage States to file provisional measures requests, knowing that, despite the fact that they would be unable to sustain the burden of demonstrating the requisite prima facie jurisdiction, they would obtain from the Court some pronouncements that could be interpreted as supporting their claim against the other party." 34 These passages, among others, seem to be based on the "legitimacy of legality" rather than the legitimacy of the criticized statements of the Court.

In the judgement on jurisdiction and admissibility handed down in 2006 in the same case, the Court echoed the "legitimacy statements" made in the 2002 order. It stated, in particular: "Whether or not States have accepted the jurisdiction of the Court, they are required to fulfil their obligations under the United Nations Charter and the other rules of international law, including humanitarian and human rights law, and they remain responsible for acts attributable to them which are contrary to international law. ${ }^{35}$

In the 2003 Oil platforms judgement the Court, in the first para.of the dispositif, found that

\footnotetext{
31 Para. 10.

32 Para. 4 (emphasisadded).

${ }^{33}$ Para. 6.

${ }^{34}$ Para. 9.

${ }^{35}$ Judgement of 3 February 2006 quoted above, para. 127.
} 
"The actions of the United States of America against Iranian oil platforms on 19 October and 18 April 1988 cannot be justified as measures necessary to protect the essential security interests of the United States of America under Article XX, para. 1(d), of the 1955 Treaty of Amity, Economic Relations and Consular Rights between the United States of America and Iran, as interpreted in the light of international law on the use of force;"

The para.continues, finding further that:

"the Court cannot however uphold the submission of the Islamic Republic of Iran that these actions constitute a breach of the obligations of the United States of America under Article X, para. 1, of that Treaty, regarding freedom of commerce between the territories of the parties, and that, accordingly, the claim of the Islamic Republic of Iran for reparation also cannot be upheld".

This rather peculiar dispositif reflects the reasoning of the Court. The submission by Iran was that the United States had violated its obligations under article X, para. 1, of the 1955 treaty, protecting freedom of commerce between the parties. The United States stated that it had not breached its obligations under article X, para. 1, while accepting that article XX, not precluding "measures necessary to fulfil obligations for the maintenance or restoration of international peace and security", could be considered as a defence, in case the Court had found otherwise. The United States did not insist on which article should be considered first. The Court chose to start from article XX, in light, inter alia, of the fact that "the original dispute between the parties related to the legality of the actions of the United States, in the light of international law on the use of force." ${ }^{36}$ By a complex reasoning, in which it resorted to rules on the use of force through interpretation of the 1955 Treaty provisions in light of "any relevant rules of international law applicable in the relations between the parties" under article 31, para. 3c of the Vienna Convention on the law of treaties, the Court went on to examine the action by the United States (the bombing of Iranian oil platforms), concluding that it did not meet the requirements of self-defence and that consequently it

${ }^{36}$ Para. 37. 
could not be justified under the rules of international law on the use of force. Going on to examine such action from the viewpoint of a violation of obligations under article X, para. 1, the Court found that there was no such violation.

As mentioned, both findings are set out in the same point of the dispositif so that the fourteen judges voting in favour could not vote on the two findings individually. This may be seen as indirect evidence that a compromise was struck within the Court so that a broad majority could be mustered to reject the Iranian claim provided that, somehow, the judgement stated that the United States had not complied with the international law rules on the use of force.

From the declarations and separate opinions of most of the fourteen judges of the majority it emerges, however, that there was an important divergence as regards the path followed by the Court in giving legal form to the above indicated compromise. This divergence concerns legality as, in particular, some judges argue that the judgement violated the non ultrapetita rule because the final submissions did not mention article XX. From the point of view that interests us in the present paper, however, the divergence concerns the policy followed in the judgement and shows in very clear terms different views of what enhances the legitimacy of a judgement and what detracts from such legitimacy.

Judge Simma, in his separate opinion, states:

"I consider it of the utmost importance, and a matter of principle, for the Court to pronounce itself on questions of the threat or use of force in international relations whenever it is given the opportunity to do so." 37

This statement seems to indicate that, whatever the constraints depending on the scope of the jurisdiction of the Court in the specific case, it is a policy requirement that matters as important as those concerning the use of force are addressed if connected with the dispute between the parties, even though not with the dispute as encompassed in the Court's jurisdiction. It would seem that, according to this view, the

${ }^{37} 42$ ILM 1429 (2003), para. 5. 
examination of questions relating to use of force enhances the legitimacy of the judgement.

The views expressed by judges Higgins, Kooijmans, Buergenthal and Owada in their separate opinions stress a totally different policy and notion of legitimacy. Their basic point, in legal terms, is that, as the Court found that there had been no violation of the invoked substantive article $\mathrm{X}$ of the 1955 Treaty, there was no need to examine the possible defence based on article XX and, in connection with it, on the rules on the use of force. The unnecessary consideration of this defence brought the Court to violate the non ultrapetitaprinciple. The legal discussion is, for our purposes, less interesting than the remarks on policy made by these judges, remarks from which an idea of legitimacy different from that of the judgement and of Judge Simma (again the "legitimacy of legality") emerges.

Judge Higgins states:

"It cannot ... be "desirable" or indeed appropriate to deal with a claim that the Court itself has categorized as a claim relating to freedom of commerce and navigation by making the centre of its analysis the international law on the use of force. And conversely, if the use of force on armed attack and self-defence is to be judicially examined, is the appropriate way to do so through the eye of the needle that is the freedom of commerce clause of a 1955 FCN Treaty? The answer must be in the negative." 38

Judge Kooijmans, among other arguments, holds, in his separate opinion, that:

"[...] the inevitable effect of the prominent place given to Article $\mathrm{XX}$, para. 1(d), and its interpretation in the light of general international law, combined with the first part of para. 1 of the dispositif, is that the Judgement reads more like a judgement on the legality of the use of force than as one on the violation velnon of a commercial treaty. One can only

$3842 \operatorname{ILM} 1379$ (2003), para. 26. 
wonder what the effect will be on States which are parties to comparable treaties with a compromissory clause." 39

Judge Buergenthal, in order to reach the conclusion that the Court violated the non ultrapetita rule, states:

"[...] the Court proceeds to convert a provision of the Treaty Article XX, para. 1(d) - which was clearly relevant only as a defence had there been a violation of Article X, para.1, into an opportunity to use Article XX, para. 1(d), in order to render a decision on the international law on the use of force and thus to find the actions of the United States in breach of that law [...] In my view, the Court's pronouncement on the issue not raised in the submissions of the Parties is not a statement entitled to treated as an authoritative statement of the law applicable to the actions of the United States" $"$.

Judge Owada states:

"The general problem of self-defence under international law is an extremely complex and even controversial subject both in terms of theory and practice. It is my considered view that while it is of the utmost importance for the Court to pronounce its authoritative position on this general problem in a proper context, it should do so in a context where it should be possible for the Court to deal with the problem squarely in a full-fledged manner, with all its ramifications both in terms of the law and the facts involved. Such is not the case with the present situation [...]"41

The jurisprudence of the International Tribunal for the Law of the Sea gives another example of "legitimizing statements" and of the opposing position based on the "legitimacy of legality". This emerges from judgements in various cases based on the special procedure for the prompt release of vessels and crews set out in article 292 of the UN Law of the Sea Convention. In these cases, prompt release was sought for fishing vessels caught in the French and Australian exclusive economic

\footnotetext{
3942 ILM 1391 (2003), para. 35.

4042 ILM 1404 (2003), para. 9.

${ }^{41} 42$ ILM 1417 (2003), para.s 38-39.
} 
zones of the southern Ocean while fishing in situations in which there were strong indications of "illegal, unreported and unregulated fishing." ${ }^{2}$

Professor Crawford, counsel for Australia in the Volga case, argued that: "the Tribunal should at all times seek to act in aid of regional fisheries arrangements which are the only way, now and in the long term, of preserving the world's fish stocks. ... ."43 Similar requests were made in other cases.

The Tribunal was not insensitive to these appeals. Its response was, nevertheless, rather restrained. In the first two cases it resisted the temptation to make a "legitimizing statement" in consonance with these appeals. In theCamouco judgement the point was mentioned only in dissenting opinions. ${ }^{44}$ In the Monte Confurco judgement the Tribunal summarized the arguments concerning the "general context of unlawful fishing in the region" and stated: "the Tribunal takes note of this argument." ${ }^{45}$ In the judgement on the third case, the Volga case, the Tribunal again took note of this argument. It added, however, the following statement, which can be seen as a "legitimizing" one: "The Tribunal understands the international concerns about illegal, unregulated and unreported fishing and appreciates the objectives behind the measures taken by States, including the States Parties to CCAMLR, to deal with the problem." ${ }^{46}$ The Tribunal thought it necessary, however, to state explicitly

42 On these cases, T. Treves, "'Straddling and Highly Migratory Flags' before the International Tribunal for the Law of the Sea", in: S. Charnovitz, D. P. Steger \& P. Van der Bossche (eds.), Law in the Service of Human Dignity, Essays in Honor of Florentino Feliciano, 2005, 323-335, espe. 325-331.

${ }^{43}$ Emphasis added. Statement by Professor Crawford on behalf of Australia, The Volga Case, Russian Federation v. Australia, (Judgement of 23 December 2002, ITLOS Reports 2002, p. 10) Oral Proceedings, ITLO Seychelles v. France, judgement of 18 December 2000, ITLOS Reports 2000, 86.S/PV 02/ 02 12, at 21 (Dec. 12, 2002), http://ITLOS.org/ cgi-bin/cases/case_detail.pl?id=11\&lang=en.

${ }^{44}$ Panama v. France, judgement of 7 February 200, ITLOS Reports 2000, 10, Anderson, J. \&Wolfrum, J., dissenting at p. 50, 66.

${ }^{45}$ Seychelles v. France, judgement of 18 December 2000, ITLOS Reports 2000, 86. at para. 79. Judge Anderson in his dissenting opinion states that: "This "factual background" is relevant in balancing the respective interests of France and the applicant".

46 The Volga Case, note 34 , at para 68. 
the reasons for the "legitimacy of legality" which, in its view, precluded going beyond such "taking note," "understanding," and "appreciating," even when challenged not to become "an unwitting accomplice to criminal activity." ${ }^{47}$ It stated: "The Tribunal must, however, emphasize that, in the present proceedings, it is called upon to assess whether the bond set by the Respondent is reasonable in terms of article 292 of the Convention. The purpose of the procedure provided for in article 292 of the Convention is to secure the prompt release of the vessel and crew upon the posting of a reasonable bond, pending the completion of the judicial procedure before the courts of the detaining State." 48 In a fourth judgement, in the Juno Trader case, the Tribunal reverted to taking note of the concerns relating to "illegal, unreported and unregulated fishing." ${ }^{4}$ This was probably in light of the fact that the indications of such fishing in the specific case were weaker than in the previous cases and that the fishing State had agreed in general terms with the concerns expressed on the subject by the detaining State.

\section{Conclusion: legitimacy of judgements and judicial policy}

The discussion of legitimacy of decisions of international courts and tribunals, at least as far as it could be conducted in the two sections above, seems to be about judicial policy and the perception of the implementation of such policy in public opinion in general and in the special public opinion of international courts and tribunals that is constituted by States.

Admittedly, "judicial policy" is a rather elusive term, difficult to define, notwithstanding the pioneering attempt made by Pierre-Marie Dupuy in an article published in 1995. ${ }^{50}$ In light of Dupuy's contribution

\footnotetext{
${ }^{47}$ Crawford, pleading for Australia.The Volga case, note 34, at 18.

48 The Volga case, note 34, at para 69.

${ }^{49}$ Saint Vincent and the Grenadines v. Guinea-Bissau, Judgement of 18 December 2004, ITLOS Reports 2004, 4 at para.87.

${ }^{50}$ P.-M. Dupuy, "The Judicial Policy of the International Court of Justice", in: F. Salerno (ed.), Il ruolo del giudice internazionale nell'evoluzione del diritto internazionale e comunitario, 1995, 61-82.
} 
and of my own reflections, I think it correct to use this expression while having regard to the broad objectives to be pursued by an international court or tribunal in exercising its function. In particular, judicial policy has to do with the way in which the exercise of the judicial function should balance the function of settling disputes with that of stating, clarifying and developing international law. The latter aspect includes the discussion whether moral or political values and rules incorporating or supporting them should be mentioned and upheld even when this is not necessary for the decision on the dispute. In the case of the International Court of Justice, the latter discussion is intertwined with that concerning the responsibilities of the Court, as the "principal judicial organ of the United Nations", in the maintenance of international peace and security. While the positions in these discussions can be seen as different views on the legitimacy of judicial decisions, the result of the discussion is, or should be, the judicial policy of the court or tribunal.

There is, of course, a difference between, on one side, the values that make a decision legitimate in the view of one judge and the judicial policy a single judge would like to pursue, and, on the other, the notion of legitimacy and the judicial policy emerging from the decisions of a court or tribunal. A single judge can have clear ideas on the values he wishes to support and on the ways of furthering such values in judicial policy. He may, for example, consider that the legitimacy of judgements is enhanced if all opportunities for stating lofty principles and invoking rules incorporating them are seized. He also may, for example, consider that the development of the notion of jus cogens and of its implications serves the same purpose. Another judge may be convinced that the most important component of the legitimacy of a judgement is that the judgement remains strictly within the limits of the jurisdiction conferred by the parties on the court or tribunal, and that the preferable judicial policy should be that of solving disputes without making pronouncements that are not strictly necessary for that purpose. Very seldom, however, will an idea of legitimacy and a consequent judicial policy emerge clearly in the result of the collective and collegial work of a court or tribunal. The differences between the cases examined, the differences in the composition of the court or tribunal through the years, the impact of 
the personality of different Presidents, and especially the compromises needed to reach decisions are all factors that tend to make the collective idea of legitimacy and the content of a judicial policy less evident.

It would seem, nevertheless, that one broadly held idea of legitimacy and the consequent judicial policy exists. It consists in the search for the broadest possible majority. The Oil platforms case considered above is a clear example. This policy has also, to a certain extent, been codified in the Resolution on the internal judicial practice adopted by the International Tribunal for the Law of the Sea. Under article 7, para. 2, of this resolution: "The Drafting Committee should prepare a draft judgement which not only states the opinion of the majority as it appears then to exist but which may also attract wider support within the Tribunal." $" 51$

In light of this judicial policy, and of the idea of legitimacy it presupposes, the "legitimizing statements" considered above can be seen as compensation for substantive compromise results that appear unsatisfactory from the point of view of the values that have been sacrificed in order to reach a majority. As seen in the examples given above, these statements may be incorporated in the text of the judgement and form part of the compromise reached, or be expressed in declarations and in separate or dissenting opinions. Such opinions may tend, in some cases, to strengthen the "legitimizing statements" set out in the judgement and a reading of the decision reached somehow qualified by these statements: so, for example, judge Koroma'sdeclaration in the armed activities order of 2002, quoted above, or the separate opinion, also quoted above, of judge Simma in the Oil platforms judgement of 2003. In other cases, as in the declaration of Judge Buergenthal in the Armed activities order, and the separate opinions of the same judge and of judges Higgins, Kooijmans and Owada in the Oil platforms judgement, they may pursue the objective of offsetting the "legitimizing statements" set out in the judgement by exposing their irrelevance to the solution of the dispute and by opposing them with other criteria of legitimacy, so as to strengthen

${ }^{51}$ Emphasis added. The resolution, adopted on 31 October 1997, can be read in ITLOS, Basic Texts/Textes de base (2005), 2005, 71. 
a reading of the decision which is unencumbered by complementary statements.

Tullio Treves é professor na Universitá degli Studi di Milano (Itália), ex-juiz do Tribunal for Law of the Sea, e membro do Curatorium of the Hage Academy of International Law.

Endereço profissional: Corso Matteotti n. 3, Milano, Italia - 20121. 
